\title{
HEPATITIS C VIRUS SEROPREVALENCE AND RISK FACTORS AMONG PATIENTS WITH HIV INFECTION
}

\author{
Maria Cássia J. MENDES-CORRÊA(1), Antonio Alci BARONE(2) \& Cristina GUASTINI(3)
}

\begin{abstract}
SUMMARY
The objective of this study was to evaluate the prevalence and risk factors associated with HCV infection in a group of HIV seropositive patients. We analyzed the medical records of 1,457 patients. All patients were tested for HCV infection by third generation ELISA. Whenever possible, a sample of the positive patients was also tested for HCV by PCR. HCV positive patients were analyzed according to their risk factors for both infections. The prevalence of anti-HCV positive patients was $17.7 \%$ (258 patients). Eighty-two (82) of these patients were also tested by PCR and 81 were positive for HCV virus (98\%). One hundred fifty-one (58.5\%) were intravenous drug users (IDU); 42 (16.3\%) were sexual partners of HIV patients; 23 (8.9\%) were homosexual males; 12 (4.7\%) had received blood transfusion; $61(17.5 \%)$ had promiscuous sexual habits; 14 (5.4\%) denied any risk factor; $12(4.7 \%)$ were sexual partners of IDU. Two hundred four patients mentioned only one risk factor. Among them, 28 (10.9\%) were sexual partners of HIVpositive patients. Although intravenous drug use was the most important risk factor for co-infection, sexual transmission seemed to contribute to the high HCV seroprevalence in this group of patients.
\end{abstract}

KEYWORDS: HIV-HCV; Viral Hepatitis; Epidemiology; Seroprevalence; Brazil

\section{INTRODUCTION}

Hepatitis $\mathrm{C}$ virus (HCV) and HIV share the same parenteral, sexual and vertical routes of transmission. Hepatitis $\mathrm{C}$ is primarily spread by parenteral or blood borne exposures, such as transfusion of blood products or intravenous drug use. Sexual transmission, however, can occur, occupational exposures have been reported, and perinatal transmission has been documented. This common epidemiology explains the high frequency of combined infections by this virus and HIV.

Hepatitis $\mathrm{C}$ virus (HCV) infection occurs throughout Brazil and until the recent introduction of serological tests for $\mathrm{HCV}$, the prevalence of this infection was not known. The use of screening assays for HCV in blood banks has uncovered a large population of asymptomatic carriers. Among blood donors the prevalence of antibody to HCV (anti-HCV) varies between $0.84 \%$ to $3.4 \%$ in different parts of Brazil. In São Paulo, where this study was conducted, the prevalence of antibody to $\mathrm{HCV}$ in blood donors is $0.84 \%{ }^{2}$.

Populational studies on the prevalence of virus $\mathrm{C}$ infection are not common in Brazil. Three different studies have shown it to vary between 0 to $3 \%{ }^{6,10,16}$. Patients co-infected with both HIV and HCV have a higher risk of progression to chronic liver disease than those infected with $\mathrm{HCV}$ alone ${ }^{15,17,19}$. However, little is known about the effect of co-infection on the progression of HIV disease $e^{4,14,21}$.

Limited information is available about hepatitis $\mathrm{C}$ virus infection in patients with HIV infection in Brazil ${ }^{11,12}$. This study was designed as part of a protocol of treatment of patients with chronic hepatitis $\mathrm{C}$ and HIV infections in our department. The objective was to evaluate: 1) the prevalence of $\mathrm{HCV}, 2)$ the risk factors and the association among them, in a group of HIV/HCV patients, followed at our institution from January to December, 1996.

\section{PATIENTS AND METHODS}

This study was conducted at an AIDS Outpatient Clinic, which belongs to the Department of Infectious Diseases, São Paulo University School of Medicine.

From January 1996 through December 1996, 1457 patients (1009 male, 448 female), were attended at the AIDS Outpatient Clinic and were tested for $\mathrm{HCV}$ infection.

Laboratory data was extracted from a data base used in the follow up of these patients.

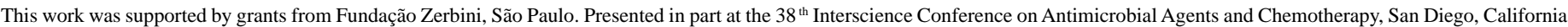
U.S.A., 1998

(1) AIDS Outpatient Clinic, Hospital das Clínicas, School of Medicine, Infectious Diseases Department, University of São Paulo, SP, Brazil.

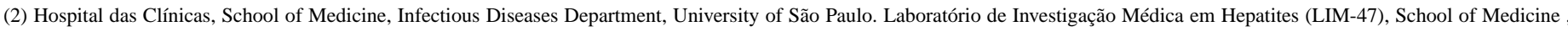
University of São Paulo, SP, Brazil.

(3) AIDS Outpatient Clinic, Hospital das Clínicas, School of Medicine, Infectious Diseases Department, University of São Paulo, SP, Brazil.

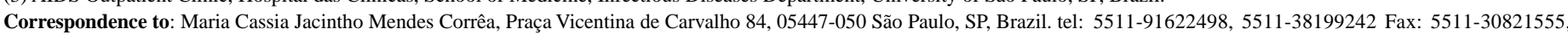
5511 -30851755, e-mail: cassiamc@uol.com.br 
Tests for anti-HCV were done by ELISA (Abbott HCV EIA second generation and third generation) according to the manufacturer's instructions. HCV RNA was investigated by the "nested" polymerase chain reaction (PCR) using two sets of oligonucleotide primers derived from 5' non-coding region. All serologic studies were performed at the Central Laboratory of Hospital das Clinicas.

PCR tests were performed at the Laboratório de Investigação Médica em Hepatites da Faculdade de Medicina da Universidade de São Paulo. Medical records from 258 patients, co-infected by HIV and HCV were reviewed.

Demographic data, risk behaviors and clinical information were obtained from medical records and the data base used in follow up of these patients. Ninety five out of these 258 patients were also interviewed by one of the authors, comprising questions involving identification, demographic characteristics, AIDS/hepatitis knowledge, AIDS treatment, risk factors (use of intravenous illegal drugs, blood transfusion, sexual behavior, possible sexual contact with someone seropositive for either HIV or HCV, use of inhaled drugs, body piercing, tattooing). When answering the questions, the patients were asked about their sexual habits and could choose between the following categories: heterosexual, bisexual, male or female homosexual. All patients were also asked about the frequency of their sexual practice. Sexual promiscuity was defined as more than two different sexual partners during the last six months.

Statistical analysis of risk factors was performed using correspondence analysis technique ${ }^{8}$. This is an exploratory multivariate analysis that represents each level of categorical variables in a two-dimensional plan. The association between two factors may be interpreted by the size of the angles formed between vectors from the origin to each point. The smaller the angle between two levels of different factors, the stronger is the association between them.

\section{RESULTS}

The estimated prevalence of anti-HCV antibodies among the 1,457 patients tested for $\mathrm{HCV}$ was $17.7 \%$ with $95 \%$ confidence interval of [15.8\%; 19.8\%]. Among the 258 anti-HCV positive patients, 82 were also tested by HCV-RNA by "nested" polymerase chain reaction ("nested" PCR) and 81 were positive for $\mathrm{HCV}$ virus (98\%).

Two hundred and two $(82.2 \%)$ anti-HCV positive patients were male and age varied from 20 to 61 years, with mean of 34.08 and standarddeviation of 7.19 years.

The frequency of each risk factor in these patients can be seen on Table 1.

One single factor was mentioned by $204(79.1 \%)$ patients; two combined factors, by $51(19.8 \%)$ patients and three combined factors, by $3(1.2 \%)$ patients.

Among those patients who mentioned only one risk factor: 106 $(41.1 \%)$ were intravenous drug users; $29(11.2 \%)$ had more than 2 sexual partners; $28(10.9 \%)$ were sexual partners of HIV patients (without any other risk factor for $\mathrm{HCV}) ; 14$ (5.4\%) were homosexual males; 7 (2.7\%) were sexual partners of intravenous drug users; 6 (2.3\%) had received blood transfusion and $14(5.4 \%)$ denied any of the risk factors cited above. Table 2 shows the associations of risk factors.

Through correspondence analysis it was possible to infer which risk factors were more associated to each other. Figure 1 shows the vectors representing the positive status of each risk factor. It may be observed that the vectors representing the risk factors sexual partner of HIV seropositive patients and sexual partner of intravenous drug users, have small angles between them, indicating association between these risk factors.

\section{DISCUSSION}

The prevalence of antibodies to HCV in HIV infected patients varies according to the risk factor for HCV and HIV infection and to the serological assay used. Among HIV/hemophiliacs the prevalence of anti$\mathrm{HCV}$ varies between $60 \%$ to $95 \%$, and, among HIV/IDU, it may be around $70 \%{ }^{19}$.

The prevalence of anti-HCV may also be underestimated by fluctuations or spontaneous disappearance of antibodies to HCV in HIV seropositive patients. WOOLEY et al. ${ }^{20}$ found out that 18 out of $52 \mathrm{HIV}$ positive patients, negative for anti-HCV, had HCV-RNA in plasma by polymerase chain reaction test.

Our study has shown that among 1,457 HIV-infected patients, $17.7 \%$ were co-infected by HCV. This seroprevalence is much higher than the prevalence among blood donors or the seroprevalence obtained through populational studies in Brazil. Such high seroprevalence is easy to understand when we analyze the epidemiology of HIV infection in Brazil.

Table 1

Prevalence and $95 \%$ confidence interval of each risk factor

\begin{tabular}{|c|c|c|c|}
\hline Risk Factor & $\mathrm{N}$ & prevalence & $95 \%$ confidence interval \\
\hline Intravenous drug users & 151 & $58.5 \%$ & {$[52.2 ; 64.6]$} \\
\hline Promiscuous sexual habits & 61 & $23.6 \%$ & {$[18.6 ; 29.3]$} \\
\hline Sexual partners of HIV seropositive patients & 42 & $16.3 \%$ & {$[12.0 ; 21.4]$} \\
\hline Homosexual males & 23 & $8.9 \%$ & {$[5.7 ; 13.1]$} \\
\hline Received blood transfusion & 12 & $4.7 \%$ & {$[2.4 ; 8.0]$} \\
\hline Sexual partners of intravenous drug users & 12 & $4.7 \%$ & {$[2.4 ; 8.0]$} \\
\hline Denied any of the risk factors listed above & 14 & $5.4 \%$ & {$[3.0 ; 8.9]$} \\
\hline
\end{tabular}


Table 2

Frequency of patients mentioning association among 2 or 3 risk factors

\begin{tabular}{llrr}
\hline Risk factor 1 & Risk factor 2 & Risk factor 3 & $\mathrm{N}$ \\
\hline Intravenous drug users & Sexual partners of HIV+ & & 9 \\
Intravenous drug users & Homosexual males & 5 & $3.5 \%$ \\
Intravenous drug users & Promiscuous sexual habits & $1.9 \%$ & $10.1 \%$ \\
Intravenous drug users & Sexual partners of IDU & 26 & $0.8 \%$ \\
Sexual partners of HIV+ & Homosexual males & $0.4 \%$ \\
Sexual partners of HIV+ & Sexual partners of IDU & $1.2 \%$ \\
Sexual partners of HIV+ & Received blood transfusion & & 3 \\
Homosexual males & Received blood transfusion & & 1 \\
Received blood transfusion & Promiscuous sexual habits & & $0.4 \%$ \\
Intravenous drug users & Homosexual males & Promiscuous sexual habits & $3 \%$ \\
Intravenous drug users & Received blood transfusion & Promiscuous sexual habits & $1.2 \%$ \\
\hline
\end{tabular}

\#: percentage over 258 patients; pts: patients; IDU: intravenous drug users
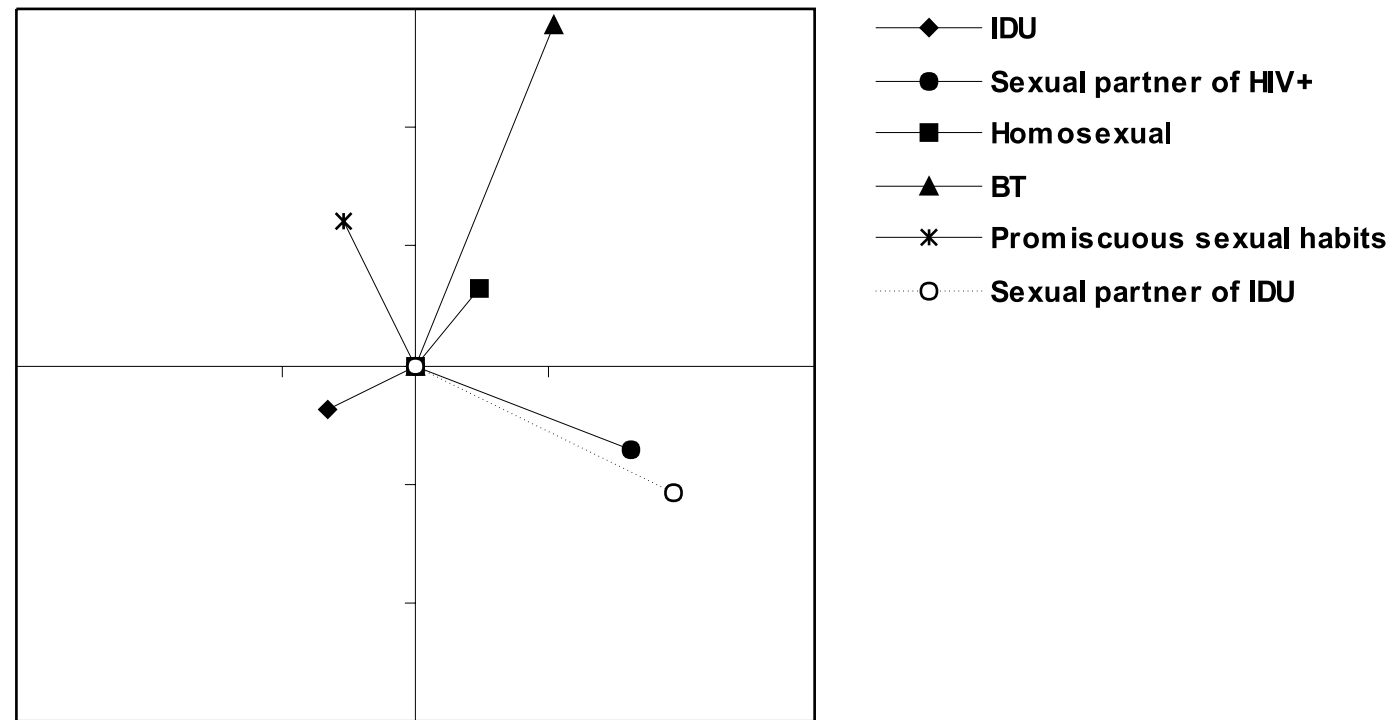

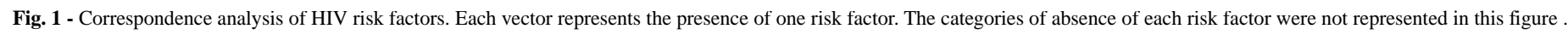

An evolving pattern in the epidemiology of this infection has become evident in most countries of the Americas, including Brazil. Substantial differences in the distribution of cases, according to exposure category, have been noted in the present decade when compared to the early 1980s. Initially, the epidemic predominated in the male homosexuals or bisexuals, hemophiliacs and others who had received blood products. However, within the past few years, there has been an increase of HIV among IDUs and heterosexuals ${ }^{18}$.

The first registered case of HIV infection in an intravenous drug user in Brazil was in 1982. This category is responsible at present for about $20 \%$ of accumulated AIDS cases in this country ${ }^{7}$.

In Brazil, the HIV epidemics among cocaine injectors, and more recently among heroin injectors, are compounded by the association of crack cocaine use and the practice of unsafe sexual behaviors. HCV infection is more rapidly acquired after initiation of intravenous drug use than other viral infections (hepatitis B virus and HIV). Also, rates of $\mathrm{HCV}$ infection among young intravenous drug users are four times higher than rates of HIV infection. More rapid acquisition of HCV infection compared with other viral infections among IDUs is likely to be caused by high prevalence of chronic HCV infection among IDUs, which results in a greater likelihood of exposure to an $\mathrm{HCV}$ infected person ${ }^{3}$.

Intravenous drug use was the most frequent risk factor involved in our study, which is in agreement with the epidemiology for HIV infection observed in Brazil, as exposed above.

It was also very interesting to observe that the second largest risk factor for HCV acquisition (16.3\%) was being a sexual partner of an HIV seropositive person. 
Among the patients who mentioned only one risk factor, 28 out of $204(10.9 \%)$ were sexual partners of HIV-positive patients and denied any other risk factor for $\mathrm{HIV} / \mathrm{HCV}$ infection. The proportion of the different risk factors involved in the groups analyzed was maintained.

Through correspondence analysis it was also possible to infer an association between the risk factors: sexual partner of HIV seropositive patients and sexual partner of intravenous drug users. This association could easily be explained by the fact that these groups may have similar exposures and are frequently compounded by the same persons.

Sexual transmission of $\mathrm{HCV}$ has been a matter of important controversy in literature. Case-control studies have reported an association between exposure to a sex contact with a history of hepatitis or exposure to multiple sex partners and the acquisition of hepatitis $\mathrm{C}$.

In contrast, a low prevalence of $\mathrm{HCV}$ infection has been reported by different studies of long term spouses of patients with chronic HCV infection. The average prevalence of HCV infection in this situation is $1.5 \%$ (range: $0 \%$ to $4.4 \%)^{3}$.

Although there are important differences among different studies on this subject, there are sufficient data to indicate that sexual transmission of HCV may occur, but that this virus is probably inefficiently spread through this route.

A more precise way to examine the issue of sexual transmission is to test the monogamous sexual partners of HCV-infected individuals. LISSEN et al..$^{9}$ examined 147 such heterosexual partners, who denied intravenous drug use or blood transfusion. According to this study the anti-HCV prevalence in stable heterosexual partners of HCV/HIV index cases was 2.2 times higher than in stable heterosexual partners of index cases reactive for anti-HCV only $(9.2 \%$ vs. $4.1 \%)$.

Among partners of hemophilics co-infected with HCV/HIV, BRETTLER et al. reported an average prevalence of HCV infection of $3 \%$.

EYSTER et al. also studied female sexual partners of anti-HCV positive hemophiliacs ${ }^{5}$. According to this study, female sexual partners of anti-HCV positive hemophiliacs were found to be at four times greater risk of acquiring $\mathrm{HCV}$ if the hemophiliac was co-infected with HIV.

Our study has shown a significant proportion of HCV/HIV patients who mentioned, as their only risk factor, the fact of being sexual partners of HIV-positive patients.

Although we do not know the HCV status of those HIV partners, it is possible that most of them were probably HCV positive, as well. It would be interesting to suppose that HIV infection could increase the chances of sexual HCV transmission.

Some studies have suggested that the level of HCV viremia is higher in HIV-infected patients when compared to HIV-negative patients ${ }^{19}$. Higher HCV replication is suggested by the more frequent vertical transmission of $\mathrm{HCV}$ to newborns from HIV-infected mothers than from HIV-negative mothers. In HIV-negative mothers the risk of transmission is clearly related to the level of viremia ${ }^{13}$.
Eighty-two of our 258 anti-HCV positive patients were tested by HCV-RNA by "nested" PCR and 81 were positive (98\%). This data could suggest that patients with HIV and HCV are more likely to have active $\mathrm{HCV}$ infections with persistent viremia.

It is possible that sexual transmission of $\mathrm{HCV}$ could be enhanced in HIV-positive patients due to higher HCV viremia and also due to more active $\mathrm{HCV}$ infection with persistent viremia.

\section{RESUMO}

\section{Prevalência e fatores de risco da hepatite $\mathrm{C}$ em pacientes infectados pelo vírus da imunodeficiência humana}

O objetivo do presente estudo foi avaliar a prevalência e os fatores de risco associados à infecção pelo vírus da hepatite $\mathrm{C}$ (VHC) em um grupo de pacientes soropositivos para o HIV. Analisamos os prontuários médicos de 1.457 pacientes. O diagnóstico laboratorial de infecção pelo VHC foi feito utilizando-se ELISA de terceira geração. Uma parte dos pacientes soropositivos para VHC foram também submetidos à realização de PCR. Os pacientes soropositivos para VHC foram analisados em relação aos fatores de risco para ambas as infecções. A prevalência de pacientes soropositivos para VHC foi de 17,7\% (258 pacientes). 82 desses pacientes foram testados para VHC por PCR e $81(98 \%)$ apresentaram-se com resultado positivo. $151(58,5 \%)$ referiram uso de drogas endovenosas (UDE), 42 (16,3\%) eram parceiros sexuais de pacientes infectados pelo HIV, $23(8,9 \%)$ eram homossexuais masculinos, 12 (4,7\%) tinham recebido transfusão sanguínea, 61 $(17,5 \%)$ referiram promiscuidade sexual, $14(5,4 \%)$ negaram qualquer fator de risco, $12(4,7 \%)$ eram parceiros sexuais de UDE. 204 pacientes referiram apenas um fator de risco, 51 referiram dois diferentes fatores de risco e três referiram três diferentes fatores de risco. Entre os pacientes que referiram apenas um fator de risco, $28 \mathrm{em} 204$ (10,9\%) eram parceiros sexuais de pacientes infectados pelo HIV. Embora o uso de drogas endovenosas tenha sido o fator de risco mais importante na determinação da co-infecção, a transmissão sexual parece ter contribuído para a alta soroprevalência do VHC nesse grupo de pacientes.

\section{ACKNOWLEDGMENT}

We thank Dr. Maria Aparecida Shikanai Yasuda, Professor of Infectious Diseases, School of Medicine, University of São Paulo. We also thank Professor David Uip, Chief, AIDS Outpatient Clinic, University of São Paulo.

\section{REFERENCES}

1. BRETTLER, D.B.; MANNUCCI, P.M.; GRINGERI, A. et al. - The low risk of hepatitis $C$ virus transmission among sexual partners of hepatitis $C$-infected hemophilic males: an international, multicenter study. Blood, 80: 540-543,1992.

2. CARRILHO, F.J. \& MENDES CORRÊA, M.C.J. - The magnitute of hepatitis B and C in Latin America. In: SCHINAZI, R.F.; SOMMADOSSI, J.P. \& THOMAS, H.C.,ed. Therapies for viral hepatitis. London, International Medical Press, 1998. p.25-34.

3. CENTERS FOR DISEASE CONTROL AND PREVENTION - Recommendations for prevention and control of hepatitis $\mathrm{C}$ virus (HCV) infection and $\mathrm{HCV}$-related chronic disease. M.M.W.R., 47: 1-39, 1998. 
4. DORRUCI, M.; PEZZOTTI, P.; PHILlIPS, A.N.; LEPRI, A.C. \& REZZA, G. Coinfection of hepatitis $\mathrm{C}$ virus with the human immunodeficiency virus and progression to AIDS. Italian seroconversion study. J. infect. Dis., 172: 1503-1508, 1995

5. EYSTER, M.E.; ALTER, H.J.; ALEDORT, L.M. et al. - Heterosexual co-transmission of hepatitis $\mathrm{C}$ virus (HCV) and human immunodeficiency virus (HIV). Ann. intern. Med., 115: 764-768, 1991.

6. FOCACCIA, R. - Prevalência das hepatites virais A, B, C e E. Estimativa de prevalência na população geral da cidade de São Paulo, medida por marcadores séricos, em amostragem populacional estratificada com sorteio aleatório e coleta domiciliar. São Paulo, 1998. (Tese de Livre Docência - Faculdade de Medicina da Universidade de São Paulo).

7. FONSECA, M.G.P. \& CASTILHO, E.A. - Os casos de AIDS entre usuários de drogas injetáveis. Brasil, 1980-1997. Semana Epidemiológica - 23 a 25, junho/agosto. Bol. Epidem. AIDS, 10(3): 6-14, 1997.

8. GREENACRE, M.J. - Theory and applications of correspondence analysis. London, Academic Press, 1984

9. LISSEN, E.; ALTER, H.J. \& ABAD, M.A. - Hepatitis C virus infection among sexually promiscous groups and the heterosexual partners of hepatitis $\mathrm{C}$ virus infected index cases. Europ. J. clin. Microbiol. infect. Dis., 12: 827-831, 1993.

10. MARTINS, R.M.B.; PORTO S.O.B.; VANDERBORGHT, B.O.M. et al. - Short report: prevalence of hepatitis $\mathrm{C}$ viral antibody among Brazilian children, adolescents, and street youths. Amer. J. trop. Med. Hyg., 53: 654-655, 1995.

11. MENDES CORRÊA, M.C.J.; DUARTE, M.I.S.; GUASTINI, C. et al. - Hepatitis C in patients with the immunodeficiency virus. In: CONFERENCE ON RETROVIRUS AND OPPORTUNISTIC INFECTIONS, 5., Chicago, 1998. Abstract. p. 494.

12. MENDES CORREAA, M.C.J. - Hepatitis $C$ in patients with the immunodeficiency virus, in São Paulo, Brazil. In: ANNUAL MEETING OF THE INFECTIOUS DISEASES SOCIETY OF AMERICA, 36., Denver, 1998. Abstract. p. 412 .
13. OHTO, H.; TERAZAWA, S.; SASAKI, N. et al. - Transmission of hepatitis C virus from mother to infants. The vertical transmission of hepatitis $\mathrm{C}$ virus collaborative study group. New Engl. J. Med., 330: 744-750, 1994.

14. PIROTH, L.; DUONG, M.; QUANTIN, C. et al. - Does hepatitis C virus co-infection accelerate clinical and immunological evolution of HIV-infected patients? AIDS, 12: 381-388, 1998.

15. SABIN, C.A.; TELFER, P.; PHILLIPS, N.A; BHAGANI, S. \& LEE, C.A.. - The association between hepatitis $\mathrm{C}$ virus genotype and human immunodeficiency virus disease progression in a cohort of hemophilic men. J. infect. Dis., 175: 164-168, 1997.

16. SILVA, L.; PARANA, R.; MOTA, E. et al. - Prevalence of hepatitis C virus in urban and rural population of Northeast Brazil: pilot study. Arq. Gastroent., 32: 168-171, 1995.

17. SOTO, B.; SANCHEZ-QUIJANO, A.; RODRIGO, L. et al. - Human immunodeficiency virus infection modifies the natural history of chronic parenterally-acquired hepatitis C with an unusually rapid progression to cirrhosis. J. Hepat., 26: 1-5, 1997.

18. SZWARCWALD, C.L.; BASTOS, F.I. \& CASTILHO, E.A. - The dynamics of the AIDS epidemic in Brazil: a space-time analysis in the period 1987-1995. Braz. J. infect. Dis., 2: 175-186, 1998

19. ZYLBERBERG, H. \& POL, S. - Reciprocal interations between human immunodeficiency virus and hepatitis C virus infections. Clin. infect. Dis., 23: 1117-1125, 1996.

20. WOOLEY, I.; VALDEZ, H.; HORSCH, A. et al. - Prevalence of unrecognized hepatitis $\mathrm{B}$ and $\mathrm{C}$ infections in AIDS patients with abnormal liver function tests. In: CONFERENCE ON RETROVIRUS AND OPPORTUNISTIC INFECTIONS, 6 ., Chicago, 1999. Abstract. p. 189.

21. WRIGHT, T.; HOLLANDER, H.; PU, X. et al. - Hepatitis C in HIV-infected patient with and without AIDS: prevalence and relationship to patient survival. Hepatology, 20: 1152-1155, 1994.

Received: 17 August 2000

Accepted: 31 October 2000 